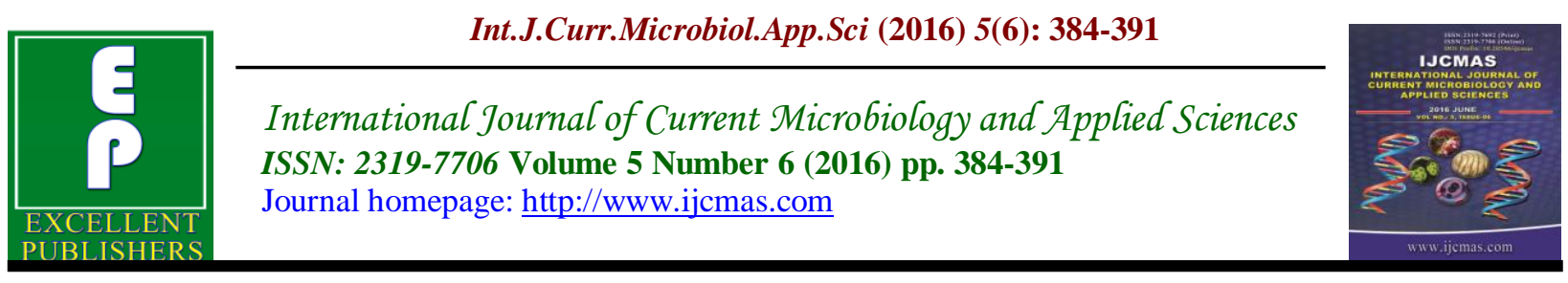

Original Research Article

http://dx.doi.org/10.20546/ijcmas.2016.506.044

\title{
Profile of HIV Positive Clients Attending an Integrated Counselling and Testing Centre of a Tertiary care Hospital in Meerut, Uttar Pradesh, India
}

\author{
Sanjiv Ahuja ${ }^{1 *}$, Anita Pandey ${ }^{1}$, Renu Vishkarma ${ }^{2}$ and Molly Madan ${ }^{1}$ \\ ${ }^{1}$ Department of Microbiology Subharti Medical College, Meerut-250005, India \\ ${ }^{2}$ ICTC, Chhatrapati Shivaji Subharti Hospital Meerut-250005, India \\ *Corresponding author
}

\begin{abstract}
A B S T R A C T
Keywords

Integrated

Counselling and

Testing Centre

(ICTC), clients,

HIV

sero-positivity, HIV/AIDS.

\begin{tabular}{l}
\hline Article Info \\
\hline Accepted: \\
16 May 2016 \\
Available Online: \\
10 June 2016
\end{tabular}

HIV/AIDS has turned out into global pandemic. Integrated Counselling and Testing Centres (ICTC) are entry points for a wide range of intervention in HIV prevention and care. To assess socio-demographic profiles, sero-positivity and risk behaviour pattern of clients attending ICTC. ICTC attached to Department of Microbiology, Subharti Medical College, Meerut. A retrospective studywas conducted among clients who visited ICTC either by self-initiative or referred by a doctor or non- governmental organization (NGO) from January 2012 to December 2014. Chi square test and Z- proportion test. Overall prevalence of HIV positivity was $1.12 \%$ of the clients attending an ICTC. A total of $81.08 \%$ males and $83.69 \%$ females who were seropositive were in the age group of 15-49years. A total of $88.04 \%$ of females were housewives, $31.08 \%$ males were having business, $72.15 \%$ were married and $66.77 \%$ were from rural areas. Hetero- sexual route was the most common route of transmission in $78.16 \%$ clients. Best antidote for HIV/AIDS remains increased awareness and adaptation of safe behavioural practices. Therefore, epidemiological studies should be carried out to find out behavioural, social and demographic factors which help in interruption and control of disease.
\end{abstract}

\section{Introduction}

AIDS has evolved from an infectious illness to a global pandemic which has affected tens of millions in less than 20 years. According to UNAIDS (2010) Global report in the world the number of people living with HIV are 33.3 million. (Kommula VM et al., 2012) India shares one tenth of the global HIV burden and overall $65 \%$ is attributed to South and South East Asia. (Praveen G and Srinivas BS, 2013) Spread of HIV/AIDS is a consequence of specific behavioural pattern and has strong socioeconomic implications. Awareness generation and lifestyle changes are preventive and control measures for HIV/AIDS and for these epidemiology of the disease in a particular region with regard to socio-demographic profile and pattern of risk behaviour of population must be understood. Under National AIDS Control Programme (NACP)-III, Integrated Counselling and Testing Centres (ICTC's) will become a hub for all HIV related 
activities. ICTC is a cost effective intervention in preventing the spread of HIV transmission and is an integral part of HIV prevention program, which provides an opportunity to learn and accept HIV status in a comfortable, convenient and confidential manner. It is the first interface between person willing to get tested and the public health system. Further, it is an entry point to care. (Ministry of Health and Family Welfare, (GOI) New Delhi: Voluntary Counseling and Testing; National AIDS Control Organization). The current study is contemplated with a view to understand the socio-demographic profile and risk behaviour of attendees of ICTC.

\section{Materials and Methods}

A retrospective study was carried out for a period of 3 years from January 2012 to December 2014 in an ICTC, attached to the Microbiology Department of CSSH, a tertiary care hospital. The study included a total of 28824 clients which were registered at ICTC. The approval from the Institutional Ethical Committee was obtained before conducting the study. All the clients received pre-test counselling. Following consent, the clients underwent HIV testing if they wished to. All clients received post-test counselling when they returned for their results. Those tested positive were given information on how to take care of themselves and referred to state government Medical college for CD4 testing and Highly active anti-retroviral therapy (HAART). Those found negative received information on change of risk behaviour. Information obtained from the counselling and the HIV test results were documented and linked by a number assigned to each client at time of first contact with the centre called Personal Identification Digit (PID).Samples were tested as per strategy and policy prescribed by National AIDS
Control Organisation (NACO). A serum sample is considered negative if the first screening test $(\mathrm{E} / \mathrm{R})$ was non-reactive. If reactive, the sample was subjected to a second test which utilizes a system different from the first one i.e. the principle and/or antigen used is different. In symptomatic patients the sample was reported as positive by two different E/R tests. However, in asymptomatic clients the same sample was subjected to a third E/R test. Such samples were reported as positive only if all the three tests gave positive results. If first positive, and $2^{\text {nd }}$ and $3^{\text {rd }}$ tests were negative it was reported negative. If $1^{\text {st }}$ and $2^{\text {nd }}$ positive and $3^{\text {rd }}$ negative or if $1^{\text {st }}$ and $3^{\text {rd }}$ tests positive and $2^{\text {nd }}$ negative the sample was reported as intermediate and the patient was called back for repeat testing after 2-4 weeks.

\section{Results and Discussion}

During the study period a total of 28824 clients were registered at ICTC. Out of them $97.46 \%$ (28091/28824) clients were tested for HIV. Number of new clients tested were $9085(97.25 \%)$ in $1^{\text {st }}$ year which increased to $9881(97.71 \%)$ and $9125(97.40 \%)$ in the $2^{\text {nd }}$ and $3^{\text {rd }}$ year respectively. In the 3 rd year there was a decrease in the prevalence of self-initiated \& ANC (Ante-natal care) clients to $5.66 \%(517 / 9125) \& 10.66 \%$ $(973 / 9125)$ from $7.09 \% \quad(644 / 9085) \quad \&$ $14.76 \%(1340 / 9342)$ in $1^{\text {st }}$ year and $6.99 \%$ $(699 / 9881) \& 15.76 \%(1557 / 9881)$ in $2^{\text {nd }}$ year. The provider initiated clients decreased to $75.93 \%(6929 / 9125)$ in the $3^{\text {rd }}$ year from $77.20 \% \quad(7014 / 9085)$ and $76.42 \%$ (7551/9881) in $1^{\text {st }}$ and $2^{\text {nd }}$ year respectively. However, significant increase in the number of clients tested from NGO's/Targeted Intervention's (TI's) increased in $3^{\text {rd }}$ year, $5.32 \%$ (486/9125) from $0.96 \%$ (87/9085)in $1^{\text {st }}$ and $0.84 \%(83 / 9881)$ in $2^{\text {nd }}$ year. The comparison of ICTC performance is given in Table 1. 
The socio-economic and demographic profiles of HIV positive attendees are elaborated in Table 2.Male to female ratio of HIV positive attendees was 2.41:1 (222/92) with 35-49 years of age group being most affected. The two transgenders 25 \& 49 years old were unmarried, homosexual, illiterate, resided in rural area and were doing some business by occupation. They came to the ICTC themselves and on testing both were positive for HIV. The epidemiological characteristics of HIV positive clients are given in Table 3 .

The married to unmarried ratio was $4.47: 1$ $(228 / 51)$. Majority of seropositive males (31.08\%) were businessmen by occupation as compared to seropositive females $(88.04 \%)$ who were housewives. Overall $81.33 \%$ clients were literate; however the literacy rate among seropositive males was $86.49 \%(192 / 222)$ as compared to $70.65 \%$ (65/92) among females. Rural to urban ratio being 2.39:1. Baghpat district was identified as the hot spot in comparison to other areas of district Meerut with $16.45 \%$ of seropositive client-age alone from the area. Heterosexual mode of transmission (78.16 $\%$ ) was responsible for sero-positivity among of HIV positive clients. Proportion of clients with HIV TB co-infection was $5.06 \%$ (16/316).

Out of total self-initiated clients and NGO's, seropositive self-initiated clients and NGO's were $6.96 \%(129 / 1852)$ and $2.51 \%(16 / 636)$ whereas, that of provider initiated and ANC seropositive clients out of total provider initiated and ANC clients were $0.77 \%$ $(166 / 21514)$ and $0.13 \%(5 / 3870)$. The three NGO's sending clients for HIV testing in the ICTC are1) Khushi clinic (now known as JL BalNikunj Samiti) works for Truck drivers and send them for testing. Number of clients tested positive are 14 and negative are 461 by this NGO.2) ASHI TI NGO works for injection drug users and send them for testing. Out of total clients (76) tested, 2 were positive for HIV. 3) GRAVIS NGO for female sex workers and send them for testing. None out of 97 clients tested was positive. The distributions of positive and negative cases of the three NGO's (TI's) are shown in Table 4.

Counselling and Testing are important for prevention and control of HIV/AIDS; however it is neither desirable nor feasible to counsel and test everyone in the general population. In ICTC the target group is the sub-population which are either vulnerable or practice high risk behaviour.

The ICTC in general is an ideal point for HIV prevention, where HIV negative individuals learn to use full array of existing services and interventions to adopt and maintain risk reduction behaviours, and HIV positive individuals use quality protection services to adopt and sustain lifelong protective behaviours and avoid the virus transmission.

The HIV sero-positivity in ICTC clients in the present study was noted to be $1.12 \%$ which is less than in studies of Ranchi (6.90\%), South Kannada (9.6\%) and West Bengal (17.1\%). (Kiran et al., 2015; Gupta M 2009; Joardan GK et al., 2006) The difference of HIV prevalence in different studies may be attributed to difference in health seeking behaviours in different parts of the country which depends on sociocultural milieu of the community. Analysis of the characteristics of clients attending the ICTC over 3 years identified a number of strong facts. High number of clients attended and tested at the ICTC during the three years and the number of clients that attended and tested almost remained same; although there was a marginal increase in the second year. However, the low percentage of self-initiated clients means the need for intensive efforts in spreading the 
HIV/AIDS awareness in the area. Male to female ratio in our study was $2.4: 1$ which is higher than the studies of Ranchi (1.89:1), Udupi (1.83:1), Karnataka (1.82:1). On the contrary, it is lower than the study reported from Ahmedabad (2.9:1). (Kiran et al., 2015; Gupta M, 2009; Praveen G and Srinivas B, 2013; Sharma R, 2009) An alarming fact that was observed in our study was that the prevalence is catching up in 2534 years age group, though highest incidence of positivity remains in the age group of 35-49 years, indicating that AIDS still threatens the most productive segment of society in the prime of their working life. It emphasizes the need of some school or college based interventions where these people can be prepared before hand. Among the sero-positive females, $43.48 \%$ are in the age group of 25-34 years. Such a high proportion of infection in young females is a matter of concern since this will lead to increased risk of mother to child transmission.

Most of the patients in our study were married and this probably because they are more accustomed to sex and therefore the hesitation to indulge in sexual activity is less. A substantial number of them were males living with their families. These people, if not informed will soon be infecting their spouses and enhancing the risk of parent to child transmission resulting in more and more "AIDS orphans".

With regard to occupation, it was observed that the attendees having some business as occupation may get easy money and indulge in some risk behaviour that favours HIVtransmission. High rate of sero-positivity among the housewives is of great concern and it might be an indication of increased HIV transmission in the area.

Higher education offers some protection against HIV. Sex education is not included in our secondary school curriculum and anybody who is illiterate or educated below or up to secondary level may not have adequate knowledge for protecting himself or herself from STD including HIV/AIDS. As such the people who are well educated are more receptive to information, education and communication and amenable to intervention.

In general, it was observed that awareness and knowledge of HIV/AIDS remains weak in rural areas and among women accounting for more seropositive clients from rural places as compared to urban areas. Unprotected heterosexual contact has come out to be the most common mode of transmission in the present study $(78.16 \%)$ which is supported by various studies in India as well as other parts of the world. (Kiran et al., 2015; Joardan GK et al., 2006; Sharma R 2009; Wani KA 2012; Khopkar U et al., 1992; Lissanc Seitu 2004; Destura RV et al., 2003)

The homosexual mode of transmission of $4.11 \%$ which was similar to study from Srinagar, Kashmir (4.1\%). (Wani KA, 2012). It was of concern in our place of setting as it can highlight spread from high risk to general population via bridge population and from permissive to conservative societies. In an Indian study (Sharma Rashmi 2009 and Khopkar et al., 1992) reported higher sero-positivity of $7.7 \%$ and $6.7 \%$ respectively in men who have sex with men (MSM). However, outside India it is on a higher side especially in African countries (Lissanc Seifu 2004). Blood transfusion comprised of $11.71 \%$ which was almost similar to study conducted by Sircar et al., (1998) of 12.1\%.In various studies from India, (Wani KA, 2013; Chakravarty J, et al., 2006 and Singh S, et al., 2009) reported $2.3 \%, 2.5 \%$ and $5.7 \%$ sero-positivity respectively through blood transfusion. 
Table.1 Comparison of ICTC Performance in three years

\begin{tabular}{|l|l|l|l|l|}
\hline Characteristics & \multicolumn{1}{|c|}{$\begin{array}{c}\mathbf{2 0 1 2} \\
\mathbf{1}^{\text {st }} \text { year }(\%)\end{array}$} & $\begin{array}{c}\mathbf{2 0 1 3} \\
\mathbf{2}^{\text {nd }} \mathbf{y e a r}(\boldsymbol{\%})\end{array}$ & $\begin{array}{c}\mathbf{2 0 1 4} \\
\mathbf{3}^{\text {rd }} \text { year }(\boldsymbol{\%})\end{array}$ & \multicolumn{1}{|c|}{ Total (\%) } \\
\hline Total Attendees & 9342 & 10113 & 9369 & 28824 \\
\hline Total tested & $9085(97.25)$ & $9881(97.71)$ & $9125(97.40)$ & $28091(97.46)$ \\
\hline Self-Initiated & $644(7.09)$ & $691(6.99)$ & $517(5.66)$ & 1852 \\
\hline Provider initiated & $7014(77.20)$ & $7551(76.42)$ & $6929(75.93)$ & 21514 \\
\hline NGO (TI) & $87(0.96)$ & $83(0.84)$ & $486(5.32)$ & 636 \\
\hline ANC & $1340(14.75)$ & $1557(15.76)$ & $973(10.66)$ & 3870 \\
\hline HIV sero-positive & $98(1.08)$ & $127(1.28)$ & $91(1.00)$ & $316(1.12)$ \\
\hline
\end{tabular}

Table.2 Demographic Profiles of HIV Positive attendees

\begin{tabular}{|c|c|c|c|c|}
\hline Variables & $\begin{array}{c}\text { Male }(n=222) \\
\text { No. }(\%)\end{array}$ & $\begin{array}{c}\text { Female }(n=92) \\
\text { No. }(\%)\end{array}$ & $\begin{array}{c}\text { Total }(n=316) \\
\text { No. }(\%)\end{array}$ & Statistics \\
\hline \multicolumn{5}{|l|}{ Age in years } \\
\hline$<14$ & $4(1.80)$ & $4(4.35)$ & $8(2.53)$ & \multirow{5}{*}{$\begin{array}{l}X^{2}=11.34, \\
p=0.023 \\
\text { (significant) }\end{array}$} \\
\hline $15-24$ & $15(6.76)$ & $12(13.04)$ & $27(8.54)$ & \\
\hline $25-34$ & $73(32.88)$ & $40(43.48)$ & $114(36.08)$ & \\
\hline $35-49$ & $92(41.44)$ & $25(27.17)$ & $118(37.34)$ & \\
\hline$>50$ & $38(7.12)$ & $11(12.96)$ & $49(15.51)$ & \\
\hline \multicolumn{5}{|l|}{$\begin{array}{l}\text { Marital } \\
\text { Status }\end{array}$} \\
\hline Married & $154(69.37)$ & $74(80.43)$ & $228(72.15)$ & \multirow{3}{*}{$\begin{array}{l}\mathrm{X}^{2}=12.94, \\
\mathrm{p}=0.002 \\
\text { (significant) }\end{array}$} \\
\hline Unmarried & $47(21.17)$ & $4(4.35)$ & $53(16.77)$ & \\
\hline $\begin{array}{l}\text { Widow/Separa } \\
\text { ted }\end{array}$ & $21(9.46)$ & $11(12.96)$ & $35(11.08)$ & \\
\hline \multicolumn{5}{|l|}{ Occupation } \\
\hline Labour & $66(29.73)$ & $1(1.09)$ & $67(21.20)$ & \multirow{7}{*}{$\begin{array}{l}\mathrm{X}^{2}=56.50, \mathrm{p}< \\
0.001 \\
\text { significant. } \\
\text { (Labour, } \\
\text { service and } \\
\text { all other } \\
\text { occupations) }\end{array}$} \\
\hline Service & $56(25.22)$ & $8(8.69)$ & $64(20.25)$ & \\
\hline Business & $69(31.08)$ & 0 & $71(22.47)$ & \\
\hline Housewife & 0 & $81(88.04)$ & $81(25.63)$ & \\
\hline Retired & $2(0.90)$ & 0 & $2(0.63)$ & \\
\hline Student & $7(3.15)$ & $1(1.09)$ & $8(2.53)$ & \\
\hline Others & $22(9.90)$ & $1(1.09)$ & $23(7.28)$ & \\
\hline \multicolumn{5}{|l|}{ Education } \\
\hline Illiterate & $30(13.51)$ & $27(29.35)$ & 59 (18.67) & \multirow{4}{*}{$\begin{array}{l}X^{2}=14.64, \\
p=0.002 \\
\text { ( significant) }\end{array}$} \\
\hline $1^{\text {st }}-5^{\text {th }}$ & $63(28.38)$ & $30(32.61)$ & $93(29.43)$ & \\
\hline $6^{\text {th }}-10^{\text {th }}$ & $91(40.99)$ & $23(25)$ & $114(36.08)$ & \\
\hline $11^{\text {th }} \&$ Above & $38(17.12)$ & $12(13.04)$ & $50(15.82)$ & \\
\hline
\end{tabular}


Table.3 Epidemiological characteristics of HIV positive clients

\begin{tabular}{|c|c|c|c|c|}
\hline Residence & & & & \\
\hline Rural & $148(66.67)$ & $61(66.30)$ & $251(66.77)$ & \multirow{2}{*}{$\begin{array}{l}\mathrm{X}^{2}=0.004, \\
\mathrm{p}=0.95 \text { (not- } \\
\text { significant) }\end{array}$} \\
\hline Urban & $74(33.33)$ & $31(33.70)$ & $105(33.23$ & \\
\hline \multicolumn{5}{|l|}{\begin{tabular}{|l} 
Pattern of Risk \\
Behaviour \\
\end{tabular}} \\
\hline Heterosexual & $174(78.38)$ & $73(79.35)$ & 247 (78.16) & \multirow{6}{*}{$\begin{array}{l}1.768 \quad p=0.621 \\
\text { not-significant } \\
\text { (Sexual } \\
\text { intercourse, } \\
\text { Parental } \\
\text { including needle } \\
\text { stick and others) }\end{array}$} \\
\hline Homosexual & $11(4.95)$ & 0 & $13(4.11)$ & \\
\hline $\begin{array}{l}\text { Through Blood \& Blood } \\
\text { products }\end{array}$ & $23(10.36)$ & $14(15.22)$ & $37(11.71)$ & \\
\hline $\begin{array}{l}\text { Through infected syringe } \\
\& \text { needle }\end{array}$ & $5(2.25)$ & 0 & $5(1.58)$ & \\
\hline Parent to child & $3(1.35)$ & $3(3.26)$ & $6(1.90)$ & \\
\hline Not specified/Unknown & $6(2.70)$ & $2(2.17)$ & $8(2.53)$ & \\
\hline \multicolumn{5}{|l|}{ Client type } \\
\hline Self-initiated & $74(33.33)$ & $53(57.61)$ & $129(40.82)$ & \multirow{4}{*}{$\begin{array}{l}16.01, \mathrm{p}=0.0003 \\
\text { significant (self- } \\
\text { initiated, } \\
\text { provider initiatec } \\
\text { and others) }\end{array}$} \\
\hline Provider-initiated & $132(59.46)$ & $34(36.96)$ & $166(52.53)$ & \\
\hline $\mathrm{NGO}(\mathrm{TI})$ & $16(7.21)$ & 0 & $16(5.06)$ & \\
\hline ANC & & $5(5.43)$ & $5(1.58)$ & \\
\hline \multicolumn{5}{|l|}{$\begin{array}{l}\text { Co-infection with } \\
\text { tuberculosis }\end{array}$} \\
\hline & $15(6.76)$ & $1(1.09)$ & $16(5.06)$ & \\
\hline
\end{tabular}

Table.4 Shows positive and negative cases from NGO's (TI's).

\begin{tabular}{|l|l|l|l|}
\hline Positive & Negative & Total & Statistics \\
\hline 16 & 620 & 636 & $\begin{array}{l}\mathrm{p}<0.001 \\
\text { (Significant) }\end{array}$ \\
\hline
\end{tabular}

In the present study only in $2.53 \%$ of the individuals, the information of the risk behaviour was not available. Similar finding was reported in $8.5 \%$ and $59.8 \%$ individuals in studies conducted in Andhra Pradesh and Udupi (Kommula et al., 2012 and Gupta M, 2009). This brings out the fact that clients were comfortable in disclosing the information about such sensitive facts in front of the counsellor in our ICTC. This is due to intensive training in strengthening the skills of counsellors under NACP-III.

Referral from TI's was comparatively poor in the present study (2.26\%) as compared to the study from Ahmedabad (6\%), where the authors feel that the increase upto six times approximately in 2014 was observed due to the Information Education and communication (IEC) activities done in the catchment areas. (Sharma R et al., 2009)

Sero-positivity percentage was higher in self-initiated clients (6.96\%) and NGO's clients $(2.51 \%)$ than in provider initiated $(0.82 \%)$. These findings are supported by a similar study done from our College earlier by Rawat et al., (2013) in which seropositivity in self-initiated clients was $5.9 \%$ 
and in provider initiated $0.68 \%$.Our study shows the sero-positivity in pregnant womento be $0.13 \%$ as compared to $0.88 \%$ and $0.45 \%$ in studies from Delhi and Andhra Pradesh respectively. (Gupta S et al., 2007; Devi AR and Shyamala R, 2012) The average HIV prevalence among women attending antenatal clinic in India in 2012-13 is $0.35 \%$ as per NACO annual report 20132014.It is much lower than studies done in Sub-saharan Africa. Montana LS et al., (2008). This may be due to differences in HIV prevalence and health seeking behaviour in different parts of the world.

Interaction of HIV-AIDS with other infectious disease is an increasing public health concern. Tuberculosis is one of the significant infectious causes of HIV related morbidity.

The registers lack certain important data like details of contact history, family size, any other person in the family with HIV etc. These may be collected from HIV positive clients during the post-test counselling and may be recorded as case studies in a certain uniform standardised semi-structured format, so that information may be compiled and utilized for programmatic intervention.

To conclude, prevention of HIV infection should theoretically be easier than prevention of water and airborne pathogens. HIV is spread as much by human behaviour as by the virus. Targeted interventions and intense Information Education and Communication (IEC) among the selected high risk groups should be carried out in different areas. Epidemiological studies have to be conducted in various settings to understand the role and complex relations of innumerable behavioural, social and demographic factors, which will help to interrupt and control the transmission of HIV/AIDS.

\section{Acknowledgement}

We acknowledge the efforts of the supervisor, counsellor and laboratory technician of ICTC and statistician $\mathrm{Mr}$ Arvind Shukla.

\section{References}

Chakravarty, J., Mehta, H., Parekh, A., Attili, S.V., Aggarwal, N.R., Singh, S.P., Sundar, S. 2006. Study on Clinico-epidemiological profile of HIV patients in eastern India. $J$. Assoc. Physicians India, 54: 854-7.

Destura, R.V., Berba, R.P., Mendoza, M.T., Velmonte, M.A., Ecarma, R.M., Zoleta, L.B., Salamat, S.S., Gomez, D.A. 2003. Profile of HIV/AIDS patients at the Philippine General Hospital: Revisiting 9 years of clinical experience. Philippine $J$. Microbiol. Infect. Dis., 32: 111-21.

Devi, A.R., Shyamala, R. 2012. The study of sero-prevalence of HIV in pregnant women in a tertiary care hospital. Der Pharmacia Lettre., 4(6): 1835-6.

Gupta, M. 2009. Profile of Clients Tested HIV Positive in Voluntary Counselling and Testing Centre of a District Hospital, Uduppi. Indian J. Community Med. 34(3): 223-6.

Gupta, S., Gupta, R., Singh, S. 2007. Seroprevalence of HIV in pregnant women in North India. BMC Infect. Dis., 7: 13

Joardar, G.K., Sarkar, A., Chatterjee, C., Bhattacharya, R.N., Banerjee, P. 2006. Profile of attendees in the voluntary counseling and testing centre of North Bengal Medical College in Darjeeling District of West Bengal. Indian J. Community Med., 31(4): 237-40.

Khopkar, U., Raj, S., Sukthankar, A., Kulka. 1992. Clinical profile of HIV 
Infection. Indian J. Dermatol. Ven., 58(3): 155-8.

Kiran, A., Kujur, M., Kumar, M., Haider, S., Kashyap, V., Sundaram, S. 2015. Profile of patients attending in ICTC, RIMS, Ranchi. 5(2):341.doi: 10.4172/2161-0711.1000341

Kommula, V.M., Mishra, A.K., Kuseniwar, G.N., Chappa, S.N., Raghava Rao, K.V. 2012. Profile of HIV positive clients in an ICTC of a private medical college, Andhra Pradesh: A situational Analysis. NJIRM, 3(2): 36-40.

LissancSeifu. 2004. Socio-demographic and clinical profile of AIDs patients in Jimma referral hospital, southwest Ethiopia. Ethiop. J. Health Dev., 18(30): 203-7.

Ministry of Health and Family Welfare, (GOI) New Delhi: Voluntary Counselling and Testing; National AIDS Control Organization, 01-08.

Montana, L.S., Mishra, V., Hong, R. 2008. Comparison of HIV prevalence estimates from antenatal care surveillance and population based surveys in sub-Saharan Africa. Sex Transm. Infect., 84 Suppl1: i78-i84.

Praveen, G., Srinivasa, B.S. 2013. Profile and Clinical features of HIV positive patients attending Integrated Counselling and Testing Centre in a Medical College Hospital of Hassan,
Karnatka. Int. J. Med. Sci. Public Health, 2(2): 297-9.

Rawat, A., Pandey, A,. Madan, M., Mishra, A., Singh, V., Shivendra. 2013. Profile of HIV positive attendees of an Integrated Counselling and Testing Centre in Meerut- A changing trend. Indian J. Public Health Res. Develop., 4(2): 44-7.

Sharma, R. 2009. Profile of attendee for voluntary counselling and testing in the ICTC, Ahmedabad. Indian J. Sex Transm. Dis., 30: 31-6.

Singh, S., Jat, K.R., Minz, R.W., Arora, S., Suri, D., Sehgal, S. 2009. Clinical profile of 516 children affected by HIV in tertiary care centre in Northern India.14 years experience. Trans. R. Soc. Trop. Med. Hyg., 103(6): 627-33.

Sircar, A.R., Tripathi, A.K., Choudhary, S.K., Misra, R. 1998. Clinical profile of Aids. A study at a referral Hospital. J. Assoc. Physicians India, 46(9): 775-8.

UNAIDS. 2010. Global report, UNAIDS Report on the Global AIDS Epidemic 2010.

Wani, KA. 2012. Clinical profile of HIV/AIDS patients in Srinagar, Kashmir, India. Int. J. Collaborative Res. Int. Med. Public Health, 4(9): 1703-12.

\section{How to cite this article:}

Sanjiv Ahuja, Anita Pandey, Renu Vishkarma and Molly Madan. 2016. Profile of HIV Positive Clients Attending an Integrated Counselling and Testing Centre of a Tertiary care Hospital in Meerut, Uttar Pradesh, India. Int.J.Curr.Microbiol.App.Sci. 5(6): 384-391. doi: http://dx.doi.org/10.20546/ijcmas.2016.506.044 